\title{
Pemodelan Deformasi Gunung Sinabung Untuk Memprediksi Posisi Pusat Tekanan Magma Dengan Model Yokoyama Menggunakan Data Citra SAR Metode PS-InSAR Mount Sinabung Deformation Modeling To Predicate The Position Of The Magma Pressure Center With The Yokoyama Model Using SAR Image Data With Ps-InSAR Method
}

\author{
Enjelius Silaban, Ira Mutiara Anjasmara* \\ Departemen Teknik Geomatika, FTSLK-ITS, Kampus ITS Sukolilo, Surabaya, 60111, Indonesia \\ *Korespondensi penulis: ira@geodesy.its.ac.id
}

Diterima: 19082021; Diperbaiki: 13112021; Disetujui: 15112021; Dipublikasi: 10012022

\begin{abstract}
Abstrak: Indonesia merupakan negara tektovulkanik dengan terdapat 129 gunung api aktif. Keberadaan gunung api tentunya berdampak positif, seperti daerah sekitar gunung menjadi subur dan berdampak negatif karena sering terjadinya bencana. Salah satu gunung aktif di Indonesia adalah Gunung Sinabung. Adanya aktivitas magma pada gunung api aktif mengakibatkan perubahan bentuk baik akibat pergerakan dan pergeseran tanah pada permukaan gunung api yang disebut deformasi. Deformasi dapat diketahui metode terestrial dengan menggunakan theodolit, Sipat darat dan metode ekstra-tersrial dengan pengamatan GPS dan pengolahan data citra SAR dengan metode pengolahan InSAR, D-InSAR, MT-InSAR yang meliputi, PS-InSAR dan SBAS. Penelitian ini dilakukan untuk mengetahui deformasi yang terjadi pada gunungapi Sinabung menggunakan metode PS-InSAR dilanjutkan memodekakan posisi sumbertekan magma dengan model Yokoyama. Model Yokoyama mengasumsikan kerak bumi tersusun atas ruangan yang elastis, dan sumber tekanannya adalah sebuah ruang kecil berbentuk spherical dengan tekanan hidrostatik yang bersifat searah dan perluasannya bersifat radial. Data SAR yang digunakan, terdiri dari terdiri dari 7 citra akusisi ascending dan 8 citra akusis descending pada tanggal akuisisi 1 Oktober hingga 31 Desember 2020. Dengan melakukan pengolahan citra secara ascending dan descending, LOS velocity rate dapat ditranformasikan ke nilai pergeseran horizontal dan vertikal. Hasil pengolahan PS-InSAR menunjukkan LOS velocity rate berkisar 394,1 mm/tahun sampai $320,7 \mathrm{~mm} / \mathrm{tahun}$ arah ascending dan secara descending menunjukkan LOS velocity rate berkisar $-277,5 \mathrm{~mm} / \mathrm{tahun}$ sampai 31.5,8 mm/tahun. Setelah melakukan decomposition LOS velocity rate, diperoleh nilai displacement titik PS pada arah horizontal dan vertikal pada titik PS1 adalah $(0,288 ;-0,037)$ meter, titik PS2 adalah $(0,004 ; 0,010)$ meter dan titik PS3 adalah $(0,041,-0,084)$ meter. Sehingga diperoleh posisi pusat tekanan magma menggunkan nilai pergeseran horizontal pada gunung sinabung berdasarkan model yokoyama terletak pada koordinat $03^{\circ} 10^{\prime} 02,64^{\prime} \mathrm{LU}$ dan 98 $24^{\prime} 26,64^{\prime \prime}$ 'BT pada kedalaman 11850 meter. Sementara, Posisi pusat tekanan magma menggunkan nilai pergeseran vertikal terletak pada koordinat $03^{\circ} 09^{\prime} 54,72,64^{\prime \prime} \mathrm{LU}$ dan 98 $24^{\prime}$ '18,36'BT pada kedalaman 11250 meter.
\end{abstract}

Copyright (C) 2022 Geoid. All rights reserved.

\begin{abstract}
Indonesia is a tectovolcanic country with 129 active volcanoes. The existence of a volcano certainly has a positive impact, such as the area around the mountain becomes fertile and has a negative impact due to frequent disasters. One of the active volcanoes in Indonesia is Mount Sinabung. The existence of magma activity in active volcanoes causes changes in shape due to the movement and shift of the soil on the surface of the volcano which is called deformation. Deformation can be determined by terrestrial methods using theodolite, land Sipat and extraterrestrial methods with GPS observations and processing of SAR image data using InSAR, D-InSAR, MT-InSAR processing methods which include, PS-InSAR and SBAS. This research was conducted to determine the deformation that occurs in the Sinabung volcano using the PS-InSAR method followed by modeling the position of the magma compression source using the Yokoyama model. The Yokoyama model assumes that the Earth's crust is composed of elastic spaces, and the source of the pressure is a small spherical space with hydrostatic pressure that is unidirectional and its expansion is radial. The SAR data used consists of 7 ascending acquisition images and 8 descending acquisition images on the acquisition date of October 1 to December 31, 2020. By processing the image in ascending and descending ways, the LOS velocity rate can be transformed into horizontal and vertical shift values. The results of PSInSAR processing show that the LOS velocity rate ranges from $394.1 \mathrm{~mm} /$ year to $320.7 \mathrm{~mm} / \mathrm{year}$ in the ascending direction and in descending direction, the LOS velocity rate ranges from $-277.5 \mathrm{~mm} / \mathrm{year}$ to $31.5 .8 \mathrm{~mm} / \mathrm{year}$. After decomposing the LOS velocity rate, the displacement value of the PS point in the horizontal and vertical directions at the PS1 point is $(0.288 ;-0.037)$ meters, the PS2 point is $(0.004 ; 0.010)$ meters and the PS3 point is $(0.041,-0.084)$ meters. So that the position of the center of magma pressure using the horizontal shift value on Mount Sinabung based on the Yokoyama model is located at coordinates $03^{\circ} 10^{\prime} 02.64^{\prime \prime} \mathrm{N}$ and $98^{\circ} 24^{\prime} 26.64^{\prime \prime} \mathrm{E}$ at a depth of 11850 meters.
\end{abstract}


Meanwhile, the position of the magma pressure center using the vertical shift value is located at coordinates $03^{\circ} 09^{\prime} 54,72,64^{\prime \prime} N$ and $98^{\circ} 24^{\prime} 18,36^{\prime \prime} B T$ at a depth of 11250 meters.

Kata Kunci: Deformasi, PS-InSAR, Model Yokoyama

Cara untuk sitasi: Silaban, E., Anjasmara, I.M., (2021). Pemodelan Deformasi Gunung Sinabung Untuk Memprediksi Posisi Pusat Tekanan Magma Dengan Model Yokoyama Menggunakan Data Citra SAR Metode PS-InSAR. Geoid, $17(1), 133-142$.

\section{Pendahuluan}

Indonesia merupakan negara tektovulkanik dengan banyak gunung api aktif dengan 129 gunung api aktif yang berada di Indonesia (BPPTKG, 2016). Keberadaan gunung api di Indonesia tentunya berdampak positif bagi Indonesia seperti daerah sekitar gunung akan menjadi subur dikarenakan magma yang keluar dari perut bumi menjadi lava akan membawa unsur hara yang sangat dibutuhkan oleh tanaman. Selain itu keberadan gunung api juga dapat berdampak negatif dengan terjadinya berbagai bencana alam magma yang keluar menyebabkan hujan abu panas yang mengganggu aktivitas manusia, hewan dan juga dapat mengakibatkan kematian pada tumbuhan.

Di Kabupaten Karo, Sumatera Utara terdapat satu gunung api yang masih aktif sampai dengan saat ini yaitu Gunung Sinabung, Gunung Sinabung terletak pada koordinat puncak $03^{\circ} 10^{\prime} \mathrm{LU}$ dan $98^{\circ} 23,5^{\prime}$ BT dengan puncak tertinggi gunung api ini adalah 2.460 meter dari permukaan laut yang menjadi puncak tertinggi kedua di Sumatera Utara. Gunung api Sinabung tercatat selama 27 Agustus 2010 - 7 April 2011 terjadi beberapa kali letusan yang diantaranya merupakan letusan freatik. Status Gunung api Sinabung berubah dari tipe-B menjadi tipe-A (Pusat Vulkanologi dan Mitigasi Bencana Geologi, 2013).

Adanya aktivitas magma pada gunung api aktif dapat mengakibatkan perubahan bentuk baik akibat pergerakan dan pergeseran tanah pada permukaan gunung api yang disebut deformasi. Deformasi merupakan salah satu fokus pembelajaran ilmu geodesi hal ini didukung dengan semakin berkembangnya teknologi pada bidang geodesi untuk pemantauan deformasi. Deformasi yang terjadi dapat diketahui dengan berbagai metode baik secara terestris maupun secara ekstra-terestrial. Secara Terestrial dapat dilakukan dengan menggunakan theodolit, Sipat darat maupun Global Positioning System (GPS). Sementra secara ekstra-tersrial dapat dikakukan dengan pengolahan data citra Synthetic Aperture Radar (SAR) dengan metode pengolahan Interferometry Synthetic Aperture Radar (InSAR), Differential InSAR (D-InSAR), Multi Temporal InSAR (MTInSAR) yang meliputi, Permanent Scatterers InSAR (PS-InSAR) dan Small Baseline Subset (SBAS) (Salsabil, 2019).

Pada penelitian kali ini dilakukan penerapan metode PS-InSAR untuk mengetahui deformasi yang terjadi pada Gunung api Sinabung. PS-InSAR merupakan salah satu metode Multi Temporal InSAR dimana menyelesaikan permasalahan terkait dekorelasi dan delay atmosferik yang terjadi pada teknik InSAR konvensional. Satelit radar yang mengorbit sampai saat ini adalah satelit SENTINEL-1B dengan sensor SAR (Synthetic Aperture Radar).

Dari penelitian ini diperoleh kondisi gunung deformasi permukaan Gunung Sinabung. Dari data citra SAR tersebut nanti akan diketahui daerah yang terdeformasi ke arah ke arah vertikal baik mengalami uplift maupun subsidence dan juga pergeseran ke arah horizontal melalui pengolahan citra secara ascending dan descending. Setelah didapat besar pergeseran maka nilai tersebut akan digunakan sebagai langkah pendekatan untuk memperkirakan lokasi pusat tekanan magma menggunakan Model Yokoyama. Informasi yang diperoleh dari hasil pengolahan dapat menunjukkan aktivitas dan keberadaan kantong magma dari Gunung Sinabung. 


\section{Data dan Metode}

Lokasi penelitian ini berada di kawasan Gunung Sinabung terletak pada koordinat puncak $03^{\circ} 10^{\prime} \mathrm{LU}$ dan $98^{\circ}$ 23,5’ BT, Kabupaten Karo Sumatera Utara.

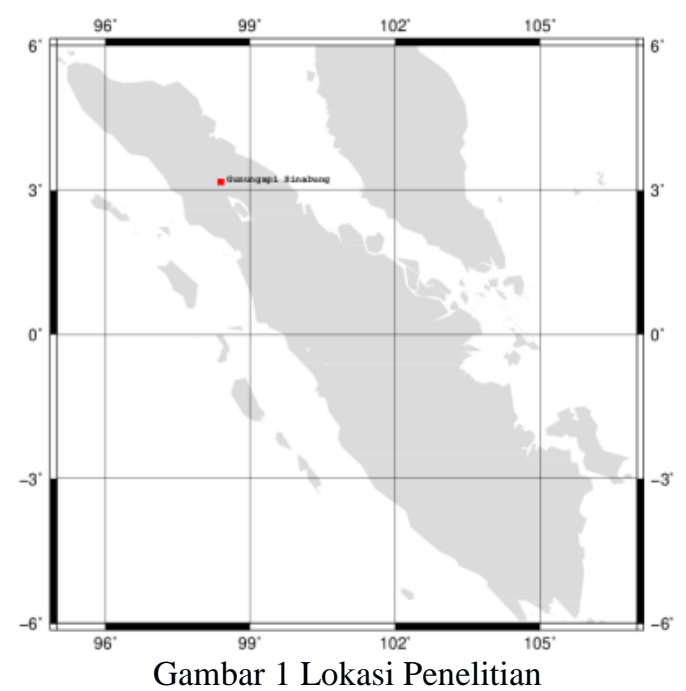

Pada penelitian ini dibutuhkan set data Citra Sentinel 1A dengan polarisasi VV, tipe produk SLC (Single Look Complex), dan mode sensor IW pada tanggal 1 Oktober - 31 Desember 2020 dan DEM SRTM (Shuttle Radar Topography Mission) 30 meter tahun 2020.

Tabel 1. Data Citra SAR Sentinel 1B arah Ascending

\begin{tabular}{|c|c|}
\hline $\mathbb{D}$ File Citra & Tangg al \\
\hline $\begin{array}{l}\text { S1B_IW_SLC_1SDV_20201001T1 14148_2 } \\
0201001 \mathrm{~T} 114218 \text { 023619_02CDFF_ACE0 }\end{array}$ & $\begin{array}{l}01 \text { Oltober } \\
2020\end{array}$ \\
\hline $\begin{array}{l}\text { S1B_IW_SLC_1SDV_20201013T114148_2 } \\
\text { 0201013T114218_023794_02D36F_9899 }\end{array}$ & $\begin{array}{l}13 \text { Oltober } \\
2020\end{array}$ \\
\hline $\begin{array}{l}\text { S1B_IW_SLC_1SDV_20201025T1 14148_2 } \\
0201025 \mathrm{T1} 14218 \text {-023969_02D8EC_87B4 }\end{array}$ & $\begin{array}{l}25 \text { Oltober } \\
2020\end{array}$ \\
\hline $\begin{array}{l}\text { S1B_IW_SLC_1SDV_20201118T1 14148_2 } \\
\text { 0201118T114218_024319_02E3D4_FB3A }\end{array}$ & $\begin{array}{l}18 \text { November } \\
2020\end{array}$ \\
\hline $\begin{array}{l}\text { S1B_IW_SLC_1SDV_20201130T1 14148_2 } \\
0201130 \text { T114218_024494_02E960_5949 }\end{array}$ & $\begin{array}{l}30 \text { November } \\
2020\end{array}$ \\
\hline $\begin{array}{l}\text { S1B_IW_SLC_1SDV_20201212T114147_2 } \\
\text { 0201212T114217_024669_02EF06_F76E }\end{array}$ & $\begin{array}{l}12 \text { Desember } \\
2020\end{array}$ \\
\hline $\begin{array}{l}\text { S1B_IW_SLC_1SDV_20201224T1 14147_2 } \\
0201224 \mathrm{T1} 14216 \text {-024844_02F4B4_7653 }\end{array}$ & $\begin{array}{l}24 \text { Desember } \\
2020\end{array}$ \\
\hline
\end{tabular}

Tabel 2. Data Citra SAR Sentinel 1B arah Descending

\begin{tabular}{|c|c|}
\hline ID File Citra & Tangga1 \\
\hline $\begin{array}{l}\text { S1B_IW_SLC_1SDV_20201007T231141_20201 } \\
\text { 007T231211_023713_02D0FD_C9 } 80\end{array}$ & $\begin{array}{l}07 \text { Oktober } \\
2020\end{array}$ \\
\hline $\begin{array}{l}\text { S1B_IW_SLC_1SDV_20201019T231141_20201 } \\
\text { O19T231211_023888_02D 668_6064 }\end{array}$ & $\begin{array}{l}19 \text { Oktober } \\
2020\end{array}$ \\
\hline $\begin{array}{l}\text { S1B_IW_SLC_1SDV_20201031T231141_20201 } \\
\text { 031T23 1211_024063_02DBE4_B5BF }\end{array}$ & $\begin{array}{l}31 \text { Okto ber } \\
2020\end{array}$ \\
\hline $\begin{array}{l}\text { S1B_IW_SLC_1SDV_202011 12T231141_20201 } \\
\text { 112T231211_024238_02E153_E920 }\end{array}$ & $\begin{array}{l}\text { 12November } \\
2020\end{array}$ \\
\hline $\begin{array}{l}\text { S1B_IW_SLC_1SDV_20201124T231140_20201 } \\
\text { 124T231210_024413_02E6E1_E33F }\end{array}$ & $\begin{array}{l}24 \text { November } \\
2020\end{array}$ \\
\hline $\begin{array}{l}\text { S1B_IW_SLC_1SDV_20201206T231140_20201 } \\
\text { 206T231210_024588_02EC73_40B9 }\end{array}$ & $\begin{array}{l}\text { 06 Desember } \\
2020\end{array}$ \\
\hline $\begin{array}{c}\text { S1B_IW_SLC_1SDV_20201218T231140_20201 } \\
\text { 218T231209_024763_02F21A_1F61 }\end{array}$ & $\begin{array}{l}18 \text { Desember } \\
2020\end{array}$ \\
\hline $\begin{array}{l}\text { S1B_IW_SLC_1SDV_20201230T231139_20201 } \\
\text { 230T231209_024938_02F7C2_A7A7 }\end{array}$ & $\begin{array}{l}30 \text { Desember } \\
2020\end{array}$ \\
\hline
\end{tabular}

Alat-alat yang digunakan pada penelitian ini terbagi menjadi 2 yaitu perangkat keras dan perangkat lunak. Perangkat lunak meliputi Laptop, mouse dan ATK serta perangkat lunak meliputi Microsoft Office, SNAP 7.0, StaMPS, Matlab. 
Pada penelitian ini, dilakukan pengolahan data citra Sentinel 1B dan data DEM STRM 30-meter data dengan software SNAP. Dari data displacement yang diperoleh, digunakan untuk memodelkan sumber tekanan magma menggunakan metode Yokoyama dengan menggunakan Matlab. Pengolahan data citra sentinel 1B dilakukan dengan langkah berikut:

1. Preprocessing :

Pada tahap ini dilakukan preprocessing citra SAR menggunakan perangkat lunak SNAP. Dengan melakukan Read Product, TOPSAR-Split dan Apply Orbit File.

2. Backgeocoding:

Pada tahapan ini dilakukan penyusunan citra master dan slave dengan meletakkan citra master yang optimal pada InSAR Stack Overview. Selain itu pada tahapan ini dilakukan koregistrasi citra master dan slave. Koregistrasi adalah proses menentukan hubungan antara dua/lebih citra SAR yang didefinisikan sebagai citra master dan citra slave. Baik tidaknya data yang yang ter-coregistration ditentukan dari nilai koherensi dan akurasi pada akhir proses InSAR.

\section{Deburst}

Pada tahapan ini ,satelit Sentinel-1 series yang menggunakan sistem subswath dan burst dengan menggabungkan burst dari pengolahan arah azimuth dan range menjadi satu citra yang utuh akan dilakukan penghilangan gap akibat metode perekaman. Berikut adalah hasil proses Debrust

\section{Interferogram Formation:}

Pada tahapan Interferogram Formation merupakan proses pembentukan beda fase antara citra slave dan citra master dan juga akan memperoleh nilai koherensi antar citra

\section{Thopo Phase Removal/Flattening:}

Setelah didapatkan raw interferogram yang didalamnya masih terdapat pengaruh dari pencitraan kesamping (slide looking) sehingga bidang proyeksi bukan pada bidang datar, maka harus dilakukan proses flattening. Proses ini bertujuan untuk mendatarkan ke bidang proyeksi. Pada tahap akan dilakukan pengurangan fase topografi dengan menambahkan DEM eksternal. DEM eksternal dapat diunduh secara otomatis pada perangkat lunak SNAP atau pun dengan menambahkan data DEM yang diunduh di luar SNAP.

\section{StaMPS Export}

Pengolahan PS-InSAR tidak sepenuhnya dapat dilakukan dengan SNAP selanjutnya dilakukan exporting data ke algoritma StaMPS. Hasil export meliputi file: dem, diffo, geo dan rscl.

\section{StaMPS Import}

Setelah data stack berhasil diekspor, skrip mt_prep_snap dijalankan menggunakan terminal pada OS Ubuntu dengan menentukan parameter amplitude dispersion. StaMPS adalah paket perangkat lunak yang dikembangkan untuk linux bash dan lingkungan matlab linux, untuk menyelesaikan semua langkah kita perlu melakukan langkah persiapan di terminal sebagai langkah pemrosesan di matlab.

Langkah pertama adalah menyiapkan lingkungan menggunakan file config.bash yang terdapat pada folder instalasi STaMPS. Selanjutnya pada pada terminal lakukan perintah source StaMPS-config.bash. selanjutnya jalankan perintah mt_prep_snap untuk memulai pengolahan StaMPS dengan format

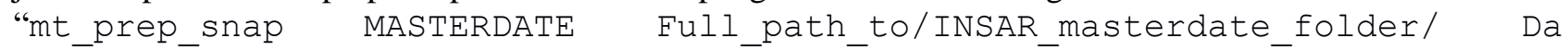

Selanjut dilakukan pengolahan dengan matlab.

8. Pengolahan Dengan StaMPS dengan Matlab

Pada pengolahan dengan matlab jalankan perintah "stamps (begin_step, end_step)". Untuk dapat menjalankan semua langkah berikut dapat dilakukan dengan menjalankan perintah stamps(1,8). Detail setiap langkah adalah sebagai berikut: 


\section{- Langkah 1 Load Data}

Mengonversi data ke dalam format yang diperlukan untuk pemrosesan PS dan menyimpannya di ruang kerja matlab. Langkah ini tidak memiliki parameter penting untuk diubah

- Langkah 2 Estimate phase noise

Pada langkah ini, memperkirakan noise fase untuk setiap piksel dalam interferogram melalui langkah iteratif. Ada banyak parameter yang mengendalikan langkah ini tetapi hampir tidak ada dokumentasi tentang cara menggunakannya dengan benar untuk pengurangan kebisingan.

- Langkah 3 PS Selection

Dengan buffering dan menggunakan nilai ambang batas, langkah ini memutuskan untuk membiarkan PS dengan fase acak jatuh dari total PS.

- Langkah 4 PS Weeding

Pada langkah ini piksel PS buruk lainnya (terlalu banyak noise atau kontribusi ground) akan disingkirkan dari piksel PS yang tersisa dengan mudah menghapus piksel yang lebih buruk dari grup, nilai antara 0,65 dan 1 cukup realistis.

- Langkah 5 merge and resampling

Pada penelitian ini, dipilih untuk memproses dalam beberapa tambalan dari mt_prep_snap, tambalan akan digabungkan di sini untuk langkah 6. Ini juga merupakan opsi untuk mengambil sampel ulang poin PS ke resolusi yang lebih rendah untuk pengurangan kebisingan.

- Langkah 6 SNAPHU phase unwrapping

Pembukaan fase menciptakan nilai perpindahan untuk hasil akhir berdasarkan proses stokastik pada semua interferogram.

- Langkah 7 Estimate spatially-correlated look angle error

Spatially-uncorrelated look angle (SULA) yang dihitung pada Langkah 3 dan dihilangkan pada Langkah 5. Pada Langkah 7, kesalahan sudut pandang berkorelasi spasial (SCLA) dihitung yang hampir seluruhnya disebabkan oleh kesalahan DEM berkorelasi spasial.

- Langkah 8 Perhitungan atmosfer menggunakan StaMPS

Langkah ini merupakan tahapan terakhir pada pengolahan dengan StaMPS. Padatahapan ini akan menyaring hasil khusus untuk gangguan atmosfer, dengan parameter scn_wavelength dan scn_time_win.

9. decomposition Line of Sight (LOS)

Pada penelitian ini akan mentransformasikan line of sight (LOS) velocity rate, hasil pengolahan dengan Citra SAR metode PS-InSAR ke nilai pergeseran secara horizontal (arah Selatan-utara dan Barat-Timur ) dan vertikal. Nilai pergeseran ini akan digunakan untuk memprediksi pusat tekanan magma dengan model Yokoyama. Untuk dapat melakukan hal tersebut maka dibutuhkan pengolahan Citra SAR secara ascending dan descending.

Setelah pengolahan PS-InSAR dengan menggunakan StaMPS, dapat dilakukan export nilai LOS setiap titik PS ke dalam file *.csv dengan menjalankan perintah export pada program matlab. Sebelum melakukan export dilakukan pemilihan titi referensi. Pada penelitian ini dilakukan pemilihan titik referensi sebagai berikut:

- titik referensi merupakan titik yang dianggap paling stabil, dengan melakukan analisis batuan paling stabil berdasarkan peta geologi berdasarkan peta geologi kementerian ESDM

- titik referensi merupakan titik stabil dengan terletak jauh dari struktur geologi baik jalur lempeng maupun patahan (berdasarkan peta geologi kementerian ESDM)

- Terdapat stasiun pemantau gunung sinabung di sekitar area referensi

Untuk dapat merubah line of sight (LOS) velocity rate kedalam displacement horizontal dan vertikal, dengan persamaan berikut (Hanssen, 2000) :

$$
\begin{aligned}
& L O S=d Z \cos (\theta)-\sin \theta[\cos (\alpha) d N+\sin (\alpha) d E] \\
& \propto \quad=\propto_{h}-\frac{3 \pi}{2}
\end{aligned}
$$


Dengan pengamatan pada arah ascending dan descending persamaan dapat dirumuskan menjadi:

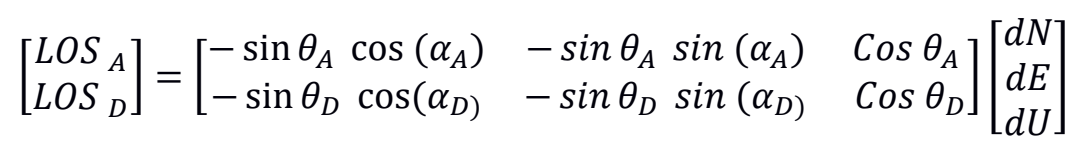

Dimana:

$\begin{array}{ll}\theta & : \text { :ncident angle } \\ \propto_{h} & : \text { : Heading angle }\end{array}$

$L=A$

$X=\left(A^{T} P A\right)^{-1} A^{T} P L$

Dimana:

$X \quad$ : Matriks parameter ( matriks yang memuat nilai parameter yang akan diperoleh dalam penelitian ini $(d N, d E$ dan $d Z)$

A : Matriks desain (matrik yang berisi nilai persamaan decomposition LOS velocity rate)

$P \quad:$ Matriks bobot (dalam penelitian setiap diangap pengamatan diangap memiliki bobot yang sama sehingga dapat disusun menjadi matriks identitas)

$L \quad$ : Matriks pengamatan (nilai LOS velocity rate pengeamatan arah ascending dan descending)

Menggunakan kombinasi pengamatan arah ascending dan descending dapat spesifik arah 2 dimensi yaitu arah Barat-Timur $(d E)$ dan arah vertikal $(d Z)$. Sementara untuk arah Utara-Selatan $(d N)$ arahnya tidak spesifik sehingga asumsi diperlukan pada penentuan karakteristik displacement. Misalnya, untuk aliran gletser sering diasumsikan bahwa alirannya sejajar dengan permukaan, yang membatasi vektor sepanjang gradien model elevasi (Hanssen, 2000). Pada penelitian ini nilai $d N$ dan $d E$ yang diperoleh digunakan untuk penentuan pergeseran arah horizontal $(d H)$, dengan persamaan:

$d H=\sqrt{d N^{2}+d E^{2}}$

10. Model Yokoyama untuk memprediksi pusat tekanan magma

Prediksi posisi kedalaman sumber tekanan magma didapatkan melalui perbandingan nilai pergeseran horizontal antara hasil pengolahan citra SAR metode PS-InSAR dengan rumus perhitungan model Yokoyama. Perhitungan model Yokoyama dilakukan dengan menjalankan program matlab.

\section{Tahap Akhir}

Prediksi posisi kedalaman sumber tekanan magma didapatkan melalui perbandingan nilai pergeseran antara pengamatan PS-InSAR dengan rumus perhitungan pergeseran model Yokoyama. Kemudian nilai keduanya dibandingkan berdasarkan input konstanta $P / \mu$ secara trial and error hingga nilai data observasi cocok dengan nilai dari model. Secara bersama saat memasukkan nilai konstanta $P / \mu$ dilakukan juga looping terhadap kedalaman. Apabila respon model sesuai dengan observasi dapat diasumsikan bahwa parameter model tersebut menunjukkan nilai parameter yang dicari, dalam hal ini lokasi dan kedalaman pusat tekanan magma. Jika fitting regresi tidak cocok dan tidak menunjukkan residual terkecil maka pemodelan harus diulang dengan mengganti konstanta $P / \mu$ hingga didapat kecocokan antara respon model dan pengamatan.

\section{Hasil dan Pembahasan}

\section{Hasil Pengolahan Data Sentinel 1B Metode PS-InSAR}

Pada penelitian ini digunakan nilai amplitude dispersion sebesar 0,400 dengan parameter densitas spasial (per $\mathrm{km}^{2}$ ) piksel yang terpilih dengan fasa acak pada nilai 80 . 


\section{- Ascending}

Dari pengolahan StaMPS kemudian akan dihasilkan pola sebaran PS yang menunjukkan velocity rate dari perpindahan pada arah LOS untuk seluruh area of interest (AOI). Pada Gambar 4.8, velocity rate untuk daerah Gunungapi Sinabung dan sekitarnya berkisar pada $-394,100 \mathrm{~mm} / \mathrm{tahun}$ sampai dengan 320,700 mm/tahun. Pada Gambar tersebut velocity rate yang menunjukkan nilai positif terjadi di sekeliling bagian dari Gunungapi Sinabung, kecuali pada bagian barat dimana velocity rate menunjukkan nilai negatif.

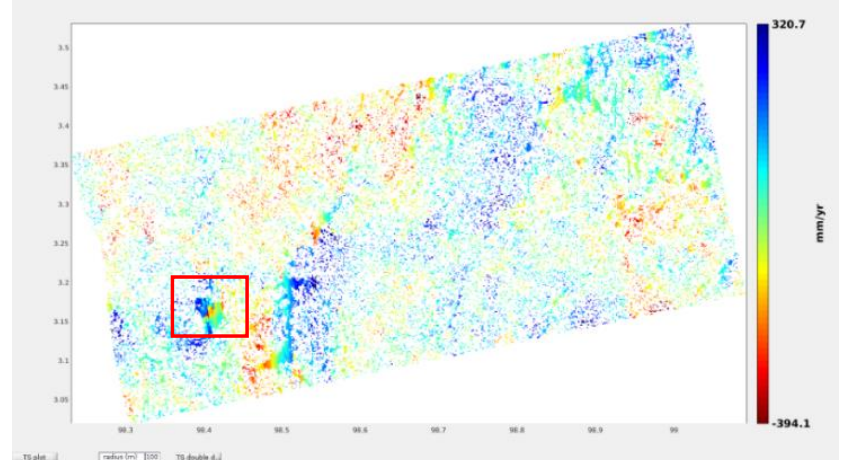

(a)

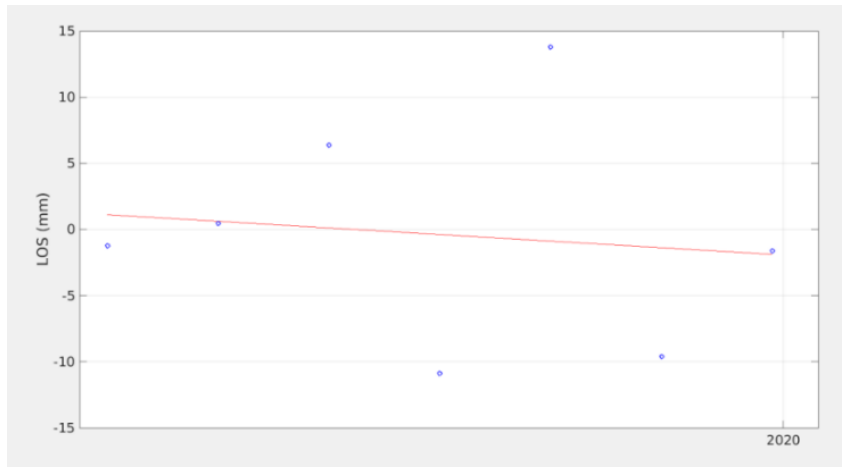

(b)

Gambar 2 LOS Displacement Velocity Rate arah ascending (a) Time Seris LOS Displacement Velocity Rate arah ascending (b)

\section{- Descending}

Dari pengolahan StaMPS kemudian akan dihasilkan pola sebaran PS yang menunjukkan velocity rate dari perpindahan pada arah LOS untuk seluruh area of interest (AOI). Pada Gambar 4.14, velocity rate untuk daerah Gunungapi Sinabung dan sekitarnya berkisar -277,500 mm/tahun sampai dengan 315,800 mm/tahun. Pada Gambar tersebut velocity rate yang menunjukkan nilai positif terjadi di sekeliling bagian dari Gunungapi Sinabung, kecuali pada bagian sebelah kanan dimana velocity rate menunjukkan nilai negatif.

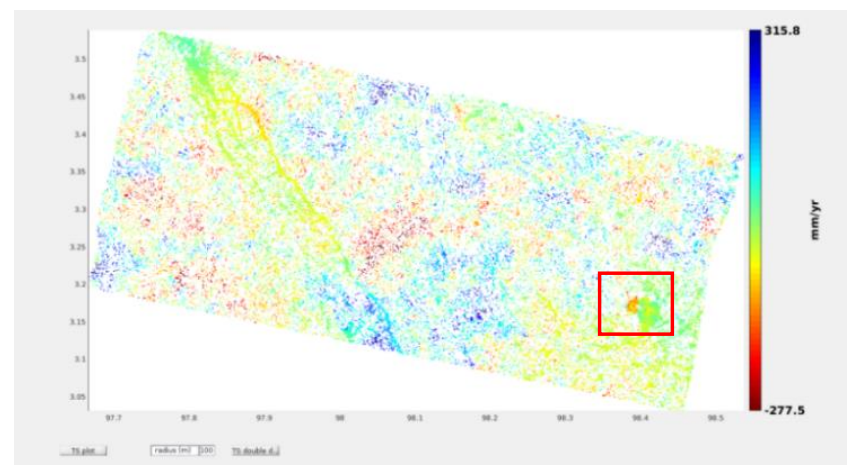

(b)

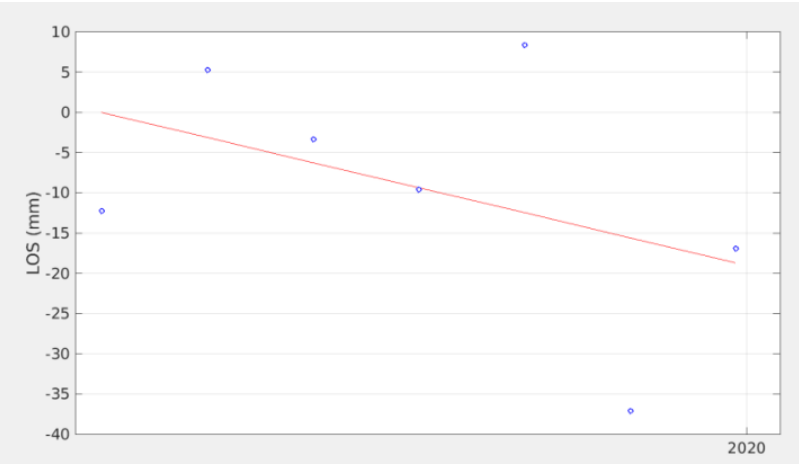

(b)

Gambar 3 Pengamatan Descending: LOS Displacement Velocity Rate (a) Time Series LOS Displacement Velocity Rate(b)

\section{Decomposition Line of Sight (LOS)}

Pola deformasi pada citra InSAR merupakan deformasi relative terhadap Line of Sight (LOS). Namun dengan melakukan decomposition Line of Sight (LOS) dari pengolahan arah ascending dan descending maka dapat diperoleh nilai pergeseran baik ke arah selatan-utara $(d N)$, barat-timur $(d E)$ dan vertikal $(d Z)$. Untuk dapat melakukan decomposition Line of Sight (LOS) dibutuhkan data incident angle $(\theta)$ dan heading angle $(\alpha)$. Pada tabel 4.4 berikut merupakan nilai $\theta$ dan $\alpha$ pada titik PS yang akan dilakukan decomposition Line of Sight (LOS) pada penelitian ini. Pada tabel 3 merupakan hasil decomposition Line of Sight (LOS) ke nilai displacement arah horizontal dan vertikal. 
Tabel 3 Tabel Nilai incident angle dan heading angle

\begin{tabular}{|c|c|c|c|c|c|}
\hline $\begin{array}{c}\text { Titik } \\
\text { Sampel }\end{array}$ & $\begin{array}{l}\text { Titik } \\
\text { PS }\end{array}$ & $\begin{array}{c}\text { Bujur } \\
\left({ }^{\circ}\right)\end{array}$ & $\begin{array}{c}\text { Lintang } \\
\left({ }^{\circ}\right)\end{array}$ & $\begin{array}{l}\text { Incident } \\
\text { Angle }\left(^{\circ}\right)\end{array}$ & $\begin{array}{l}\text { Heading } \\
\text { angle }\left(^{\circ}\right)\end{array}$ \\
\hline \multirow{2}{*}{ PS1 } & PS1AC & \multirow{2}{*}{98,395} & \multirow{2}{*}{3,174} & 42,203 & \multirow[b]{2}{*}{348,771} \\
\hline & PS2AC & & & 42,235 & \\
\hline \multirow{2}{*}{ PS2 } & PS3AC & \multirow{2}{*}{98,404} & \multirow{2}{*}{3,157} & 42,064 & \multirow{4}{*}{191,813} \\
\hline & PS1AD & & & 42,143 & \\
\hline \multirow{2}{*}{ PS3 } & PS2AD & \multirow{2}{*}{98,373} & \multirow{2}{*}{3,164} & 42,065 & \\
\hline & PS3AD & & & 42,262 & \\
\hline
\end{tabular}

Tabel 4 Nilai pergeseran titik PS hasil decomposition LOS

\begin{tabular}{lllll}
\hline Titik PS & $d N(\mathrm{~m})$ & $d E(\mathrm{~m})$ & $d Z(\mathrm{~m})$ & $d \operatorname{Hor}(\mathrm{m})$ \\
\hline PS 1 & 0,142 & 2,022 & $-0,037$ & 0,288 \\
PS 2 & 0,098 & $-0,039$ & 0,010 & 0,004 \\
PS 3 & 0,080 & 0,515 & $-0,084$ & 0,041 \\
\hline
\end{tabular}

\section{Analisa Penentuan Posisi Tekanan Magma}

Pada penelitian ini penentuan posisi tekanan magma diperoleh dengan menggunakan perhitungan pada program MATLAB (program Yokoyama). Prediksi posisi dan kedalaman sumber tekanan magma diperoleh melalui perbandingan nilai pergeseran horizontal observasi dengan pergeseran horizontal perhitungan rumus model Yokoyama. Lakukan input parameter konstanta $P / \mu$ dengan interval minimum sehingga didapatkan nilai pergeseran Model Yokoyama. Nilai pergeseran model yang diperoleh kemudian dibandingkan pergeseran observasi dengan regresi linier, perhitungan regresi akan berhenti saat didapatkan resultan dari koefisien $a$ dan $b$ bernilai 1 . Kemudian dilanjutkan dengan nilai konstanta $P / \mu$ berikutnya, terus secara trial and error hingga memperoleh interval maksimum. Setiap nilai konstanta $\mathrm{P} / \mu$ akan menghasilkan nilai lintang dan bujur, serta kedalaman tersendiri dengan pertambahan nilai tiap gridnya. Nilai posisi dan kedalaman sumber tekanan magma berdasarkan nilai pergeseran horizontal dengan nilai regresi dari setiap nilai konstanta $P / \mu$ akan menghasil nilai prediksi pusat tekanan magma. Pada nilai konstanta 0.43 akan diperoleh prediksi pusat tekanan magma.

Tabel 5 Tabel hasil prediksi pusat tekanan magma

\begin{tabular}{ll}
\hline Nilai konstanta $P / \mu$ & 0.43 \\
\hline Kedalam pusat tekanan magma & 11850 meter \\
Koordinat Lintang & $03^{\circ} 10^{\prime} 02,64^{\prime \prime}$ \\
Koordinat Bujur & $98^{\circ} 24^{\prime} 26,64^{\prime \prime}$ \\
\hline
\end{tabular}

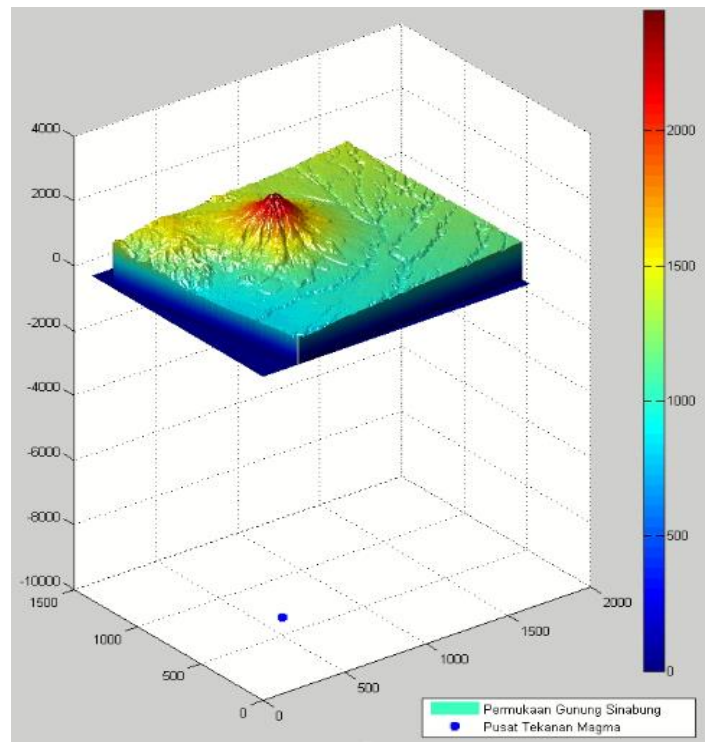

Gambar 4 Plot prediksi pusat tekanan magma berdasarkan $\boldsymbol{d H}$ 
Nilai posisi dan kedalaman sumber tekanan magma berdasarkan nilai pergeseran vertikal dengan nilai regresi dari setiap nilai konstanta $P / \mu$ akan menghasil nilai prediksi pusat tekanan magma. Pada nilai konstanta 0.43 akan diperoleh prediksi pusat tekanan magma.

Tabel 6. Tabel hasil prediksi pusat tekanan magma dari nilai $d Z$

\begin{tabular}{ll}
\hline Nilai konstanta $P / \mu$ & 0.43 \\
Kedalam pusat tekanan magma & 11250 meter \\
Koordinat Lintang & $03^{\circ} 9^{\prime} 54,72^{\prime \prime}$ \\
Koordinat Bujur & $98^{\circ} 24^{\prime} 18,36^{\prime \prime}$ \\
\hline
\end{tabular}

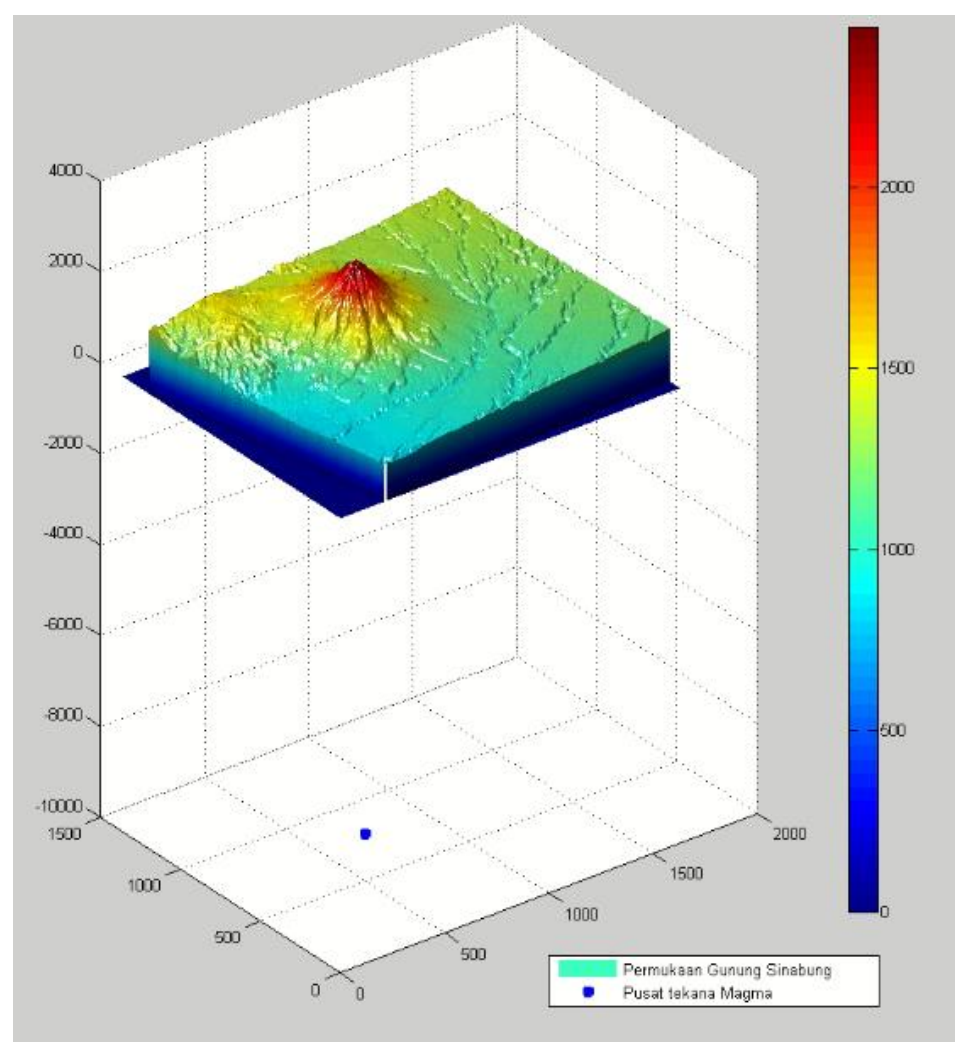

Gambar 5 Plot prediksi pusat tekanan magma dengan nilai $d Z$

\section{Kesimpulan}

Pada penelitian ini digunakan nilai amplitude dispersion sebesar 0,40 dengan parameter densitas spasial (per $\mathrm{km}^{2}$ ) dan piksel yang terpilih dengan fase acak pada nilai 80. Didapatkan hasil LOS velocity untuk setiap citra pada pengamatan ascending berkisar pada $-394,1 \mathrm{~mm} / \mathrm{tahun}$ sampai dengan 320,7 mm/tahun. Sementara pengamatan descending berkisar pada $-277,5 \mathrm{~mm} /$ tahun sampai dengan 315,8 mm/tahun. Setelah melakukan decomposition LOS velocity rate, diperoleh nilai displacement titik PS pada arah horizontal dan vertikal pada titik PS1 adalah $(0,288 ;-0,037)$ meter, titik PS2 adalah $(0,004 ; 0,010)$ meter dan titik PS3 adalah $(0,041,-0,084)$ meter. Sehingga diperoleh posisi pusat tekanan magma menggunkan nilai pergeseran horizontal pada gunung sinabung berdasarkan model yokoyama terletak pada koordinat $03^{\circ} 10^{\prime} 02,64^{\prime \prime} \mathrm{LU}$ dan $98^{\circ} 24^{\prime} 26,64^{\prime \prime}$ 'BT pada kedalam 11850 meter dengan nilai konstanta $\mathrm{P} / \mu$ sebesar 0,43 . Sementara, Posisi pusat tekanan magma menggunkan nilai pergeseran vertikal terletak pada koordinat $03^{\circ} 09^{\prime} 54,72,64^{\prime \prime} \mathrm{LU}$ dan $98^{\circ} 24^{\prime} 18,36^{\prime \prime} \mathrm{BT}$ pada kedalam 11250 meter dengan nilai konstanta $P / \mu$ sebesar 0,0023 .

\section{Ucapan Terimakasih}

Penulis mengucakan terimaksih kepada European Space Agency (ESA) yang telah menyediakan data sentinel 1B yang dipergunakan pada penelitian ini. 


\section{Daftar Pustaka}

BPPTKG, (2016). Gunung Api Lipuran Khusus Gunung Sinabung. Retrieved from <https://vsi.esdm.go.id/index.php/gunung api/liputan-khusus/g-sinabung>. dikunjungi 10 Februari 2021.

Pusat Vulkanologi dan Mitigasi Bencana Geologi, (2015). Gempabumi dan Tsunami. Retrieved from <http://www.vsi.esdm.go.id/index.php/kegiatanpvmbg/download-center/doc_details/662-leaflet-qgempabumidan-tsunamiq> dikunjungi pada 10 Februari 2021.

Hanssen, Ramon F., (2000). Radar Interferometry-Data Interpretation and Error Analysis. Netherlands: Delft University of Technology

Hooper, A.J. (2006). Persistent Scatterer Radar Interferometry for Crustal Deformation Studies and Modeling of Volcanic Deformation. Ph.D. thesis, California: Stanford University.

Hooper, A., Bekaert, D., Spaans, K., dan Arikan. M., Jan. (2012). "Recent advances in SAR interferometry time series analysis for measuring." Tectonophysics 514-517 : 1-13.

Salsabil, Sajidah, (2019). Penerapan Metode Permanent Scatterers Interferometry Synthetic Aperture Radar (Ps-InSAR) Untuk Analisis Deformasi Gunung api (Studi Kasus: Gunung api Sinabung), Surabaya: Institut Teknologi Sepuluh Nopember.

Wismaya, Yuandhika Galih, (2016). Pemodelan Deformasi Gunung Merapidengan Model Yokoyama Menggunakan Data Gps, Surabaya: Institut Teknologi Sepuluh Nopember.

This article is licensed under a Creative Commons Attribution-ShareAlike 4.0 International License. 